\title{
First observations of the behaviour of the deep-sea amphipod Dulichiopsis dianae sp. nov. (Senticaudata, Dulichiidae) in the TAG hydrothermal vent field (Mid-Atlantic Ridge)
}

\author{
Laure Corbari $^{1} \cdot$ Jean-Claude Sorbe $^{2}$
}

\begin{abstract}
A "tiny and mysterious creature swinging on a stem": that was the first observation of the new species Dulichiopsis dianae sp. nov. made during the remotely operated vehicle (ROV) dive devoted to the exploration of the surroundings of the vent site TAG (BICOSE cruise, 3550$3650 \mathrm{~m}$ ). The viewing and analysis of the high-definition pictures from several dives (PL570, PL573 and PL575) corresponding to five different locations around TAG revealed that these organisms were amphipods, hung on erected and flexible masts $(5-7 \mathrm{~cm}$ length) attached to the underlying hard substratum. Two specimens were opportunely sampled during dive PL575 (3637 m) with the suction sampler of the ROV and were identified as a new species ascribed to the genus Dulichiopsis (family Dulichiidae). The present study provides the morphological description of this new species, coupled with in situ observations of its behaviour and lifestyle in the vicinity of the TAG vent field. Taxonomic and ecological aspects of the family Dulichiidae are proposed here, as well as a review of the amphipod diversity in hydrothermal environments.
\end{abstract}

Laure Corbari

corbari@mnhn.fr

1 Muséum national d'Histoire naturelle, Institut de Systématique, Évolution, Biodiversité ISYEB - UMR 7205 - CNRS, MNHN, UPMC, EPHE, 57 rue Cuvier, CP 26, 75005 Paris, France

2 Station Marine, 2 rue Jolyet, 33120 Arcachon, France
Keywords Amphipoda · Dulichiopsis · Behaviour . Hydrothermal vents · Deep sea

\section{Introduction}

In the northern Mid-Atlantic Ridge, the TAG hydrothermal field was discovered by Rona et al. (1986) at 3500-4000 m, on a slow-spreading part of the ridge (spreading rate $\sim 4 \mathrm{~cm} /$ year). Located in an area of about $5 \mathrm{~km}$ by $5 \mathrm{~km}$, this vent field is one of the largest known hydrothermal areas, comprising a mound $200 \mathrm{~m}$ in diameter and $60 \mathrm{~m}$ high, principally composed of massive sulphides (Copley et al. 1999, 2007). The high-temperature $\left(>360^{\circ} \mathrm{C}\right)$ hydrothermal discharge occurs from a central black smoker at the summit of the mound, occupied by dense aggregations of the alvinocaridid decapod Rimicaris exoculata Williams \& Rona, 1986 (Tunnicliffe 1991; Copley et al. 2007). Despite the diverse topography of the vent field and a mosaic distribution of the benthic fauna, only two major benthic associations were recognised on the hydrothermal mound, zoned around hot black smokers, the closest one dominated by dense aggregations of $R$. exoculata and the outer one marked by anemones and gastropods (Gebruk et al. 1997). Outside the active vent areas, the bottom landscape is characterised by a series of facies of broken basalts interchanged with pelagic sediments, occupied by a clearly oligotrophic benthic community, mainly represented by passive suspension feeders (Gebruk et al. 1997). As previously pointed out by Copley et al. (1999), this background benthic community area remains poorly known.

The amphipod fauna described from hydrothermal vents comprises, up to now, 50 species spread over 27 families, with a dominance of lysianassoid species (Table 1). Among them, four species are regarded as an important component of the hydrothermal vent communities due to their great abundance 


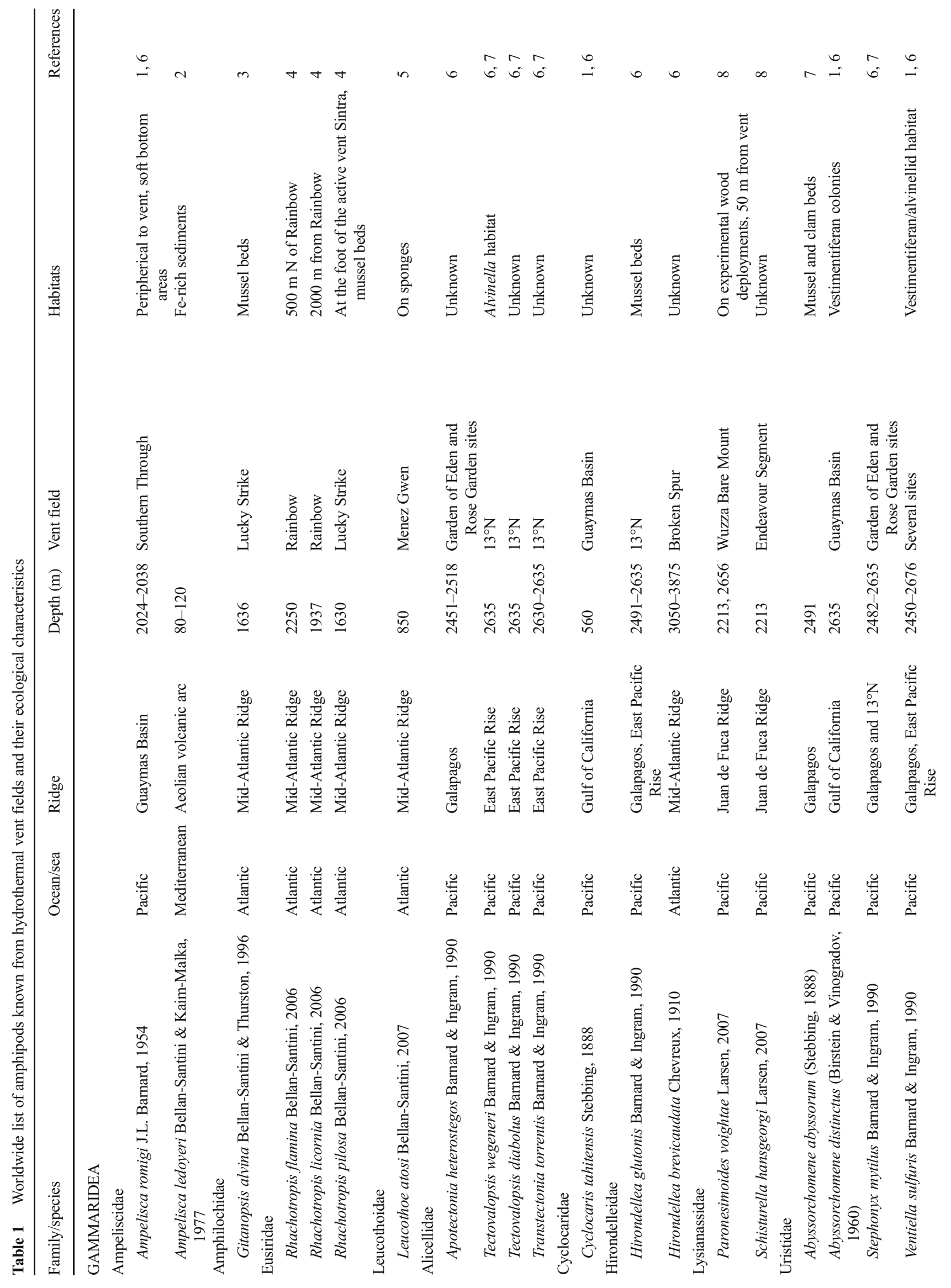



|

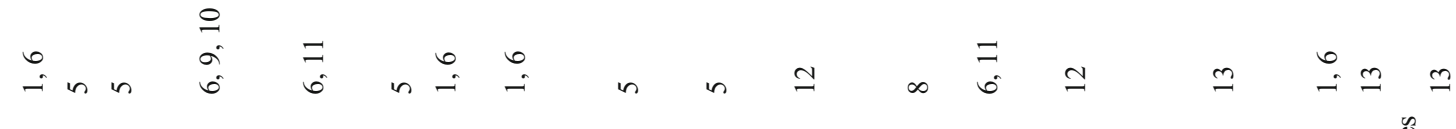

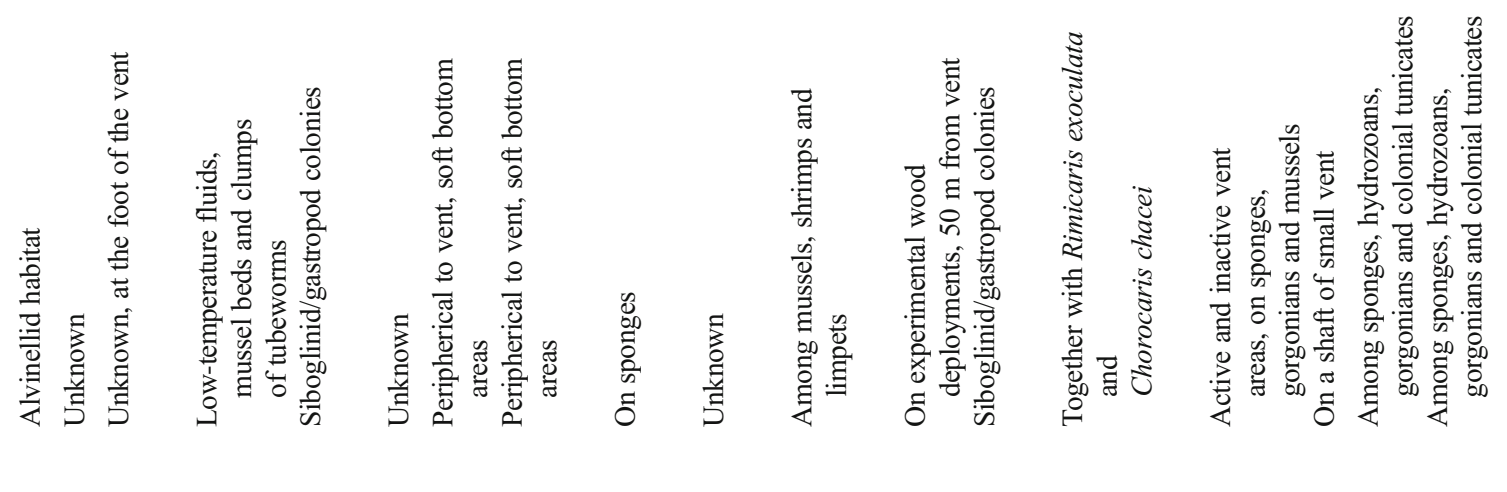
高

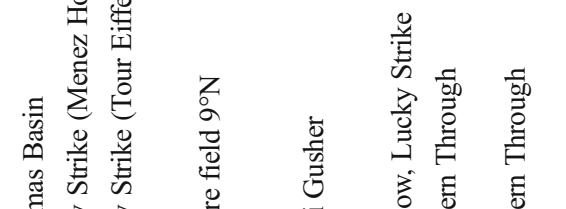

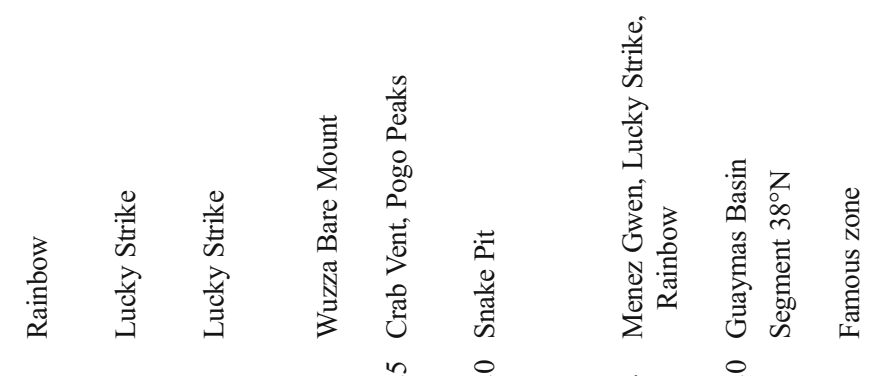

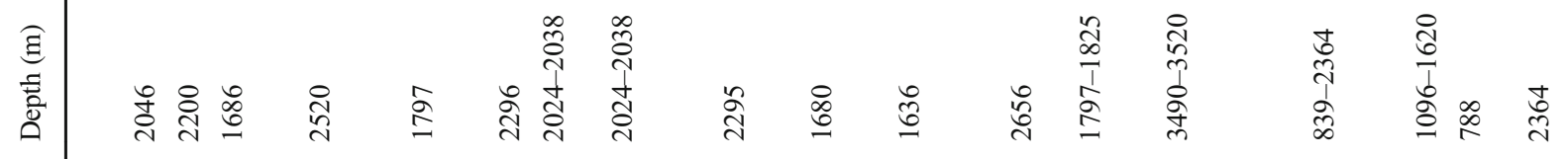

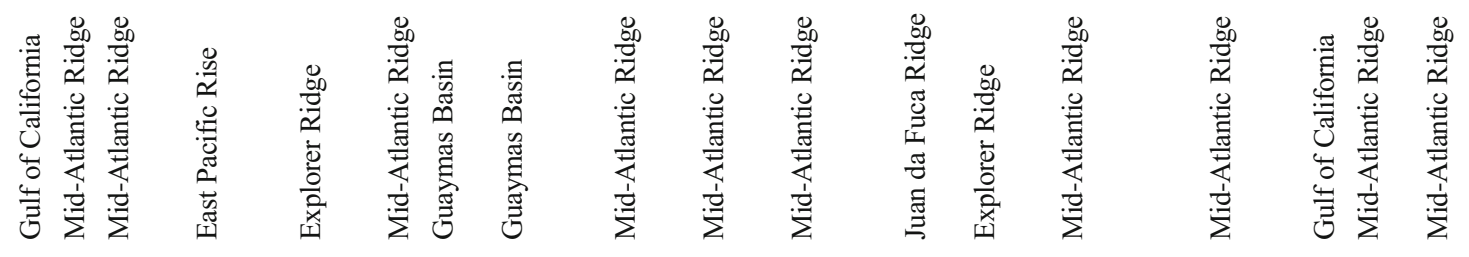

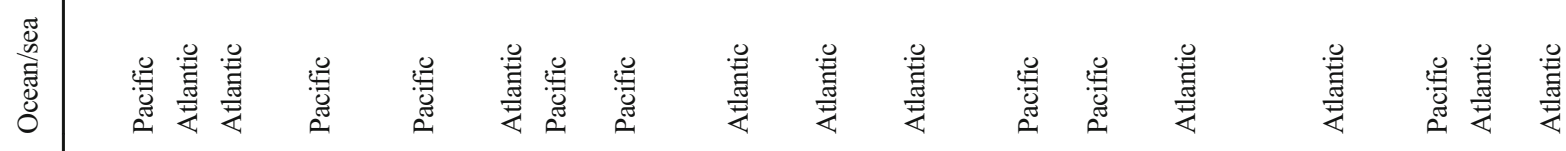

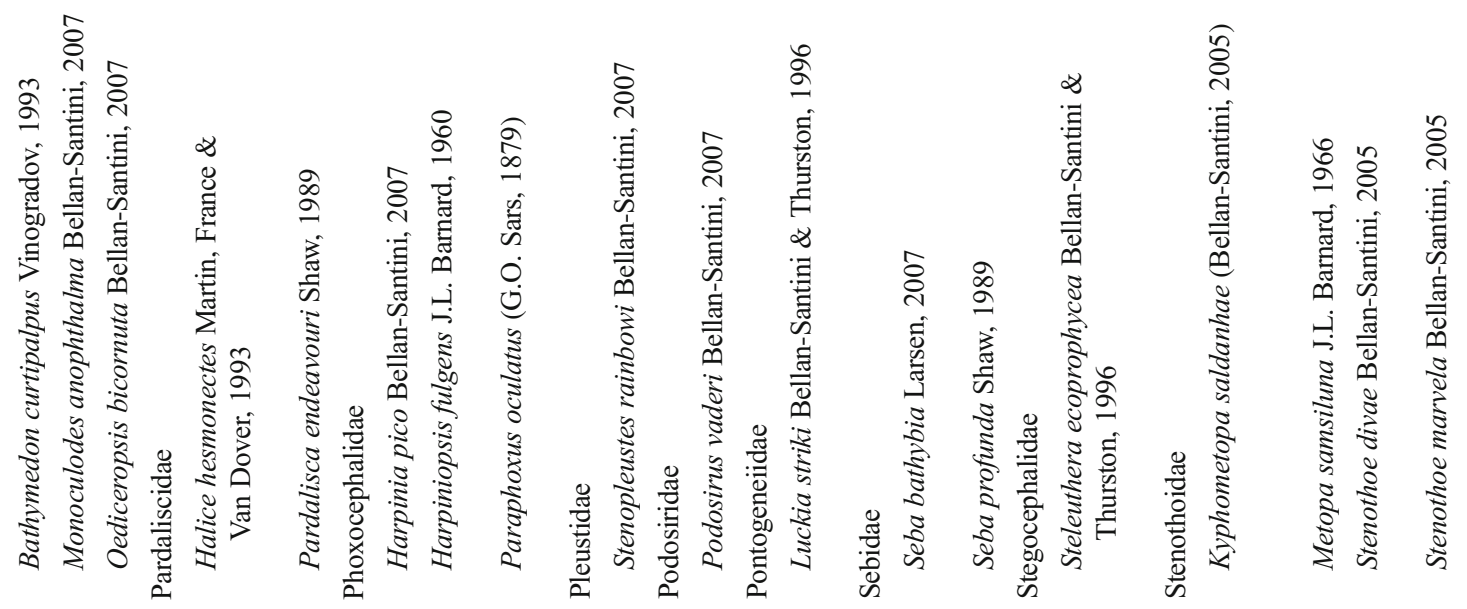




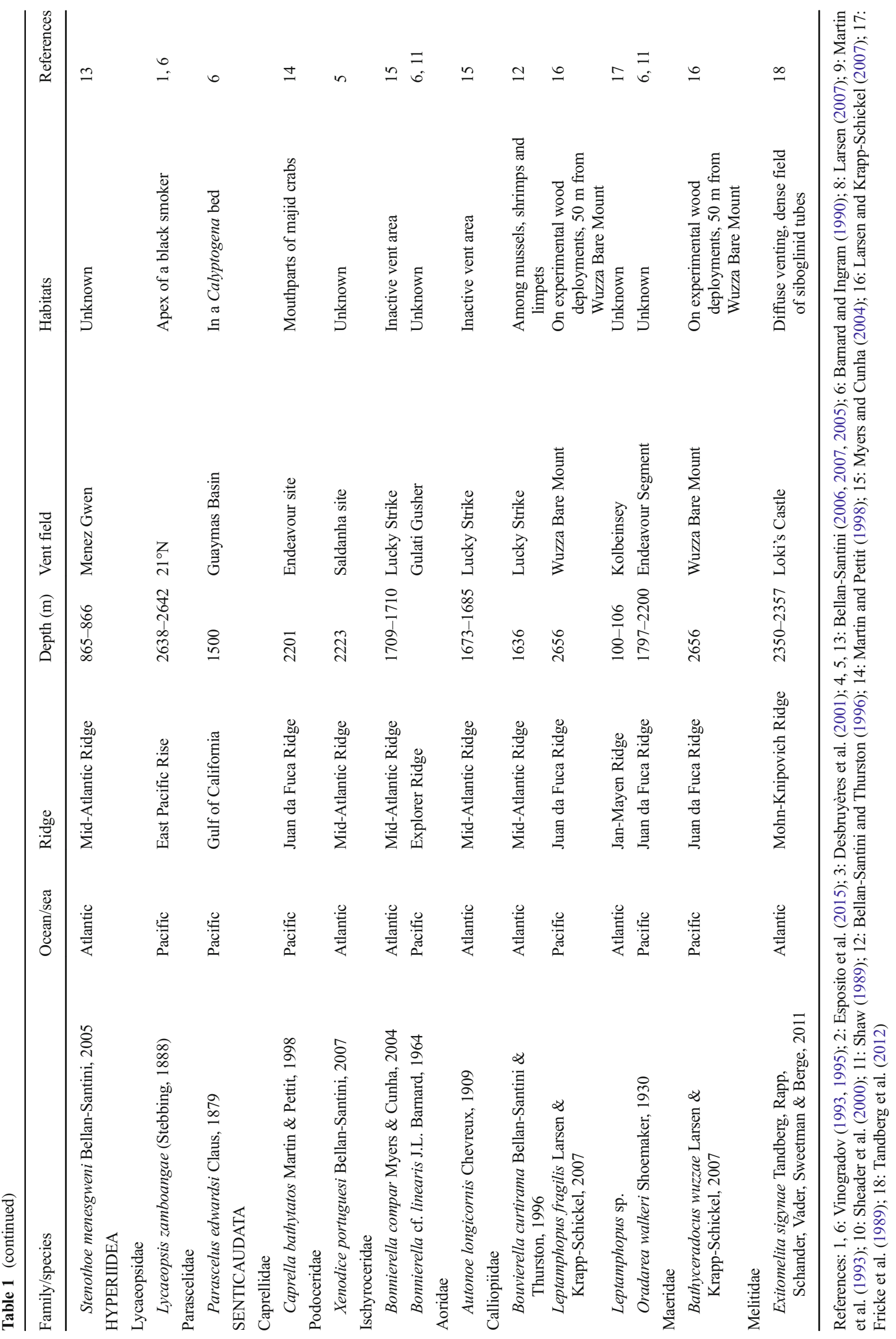


in swarms: Ventiella sulfuris Barnard \& Ingram, 1990 (family Uristidae), Halice hesmonectes Martin, France \& Van Dover, 1993 (family Pardaliscidae) from Pacific vents and Bouvierella curtirama Bellan-Santini \& Thurston, 1996 (family Calliopiidae), Luckia striki Bellan-Santini \& Thurston, 1996 (family Pontogeneiidae) from Atlantic vents. Trophic relationships and associated bacterial symbiosis have been described in $V$. sulfuris, suggesting a strong association of this amphipod with alvinellid polychaete colonies (Corbari et al. 2012). The abundance of $L$. striki has also been linked to the faunal assemblages of the mussel beds of Bathymodiolus azoricus (Cuvelier et al. 2011) but without ecological or trophic conclusions. Even though dense swarms of some of these amphipod species have been described (Kaartvedt et al. 1994; Sheader et al. 2000, 2004), little information is available on the ecological relevance of these species within the vent communities. All the other species are known to occur only in small numbers per sample and were discovered in the vicinity of hydrothermal vent fields and, thus, described as endemic from vents but without any evidence of adaptive, trophic or ecological relationships with vent communities. Beyond these observations, it seems obvious that amphipods represent an important group that should be linked either directly or indirectly to the functioning of vent communities. In the few studies dedicated to this group, their underestimated diversity due to inadequate sampling methods carried out to collect these fragile, small-sized and vagile crustaceans can lead to the conclusion that vent-related amphipods represent a "Pandora's box" that remains to be opened.

In terms of biogeography, a total of 21 amphipod species have been reported so far from the Mid-Atlantic Ridge hydrothermal vents, including the families Amphilochidae, Eusiridae, Leucothoidae, Hirondelleidae, Oedicerotidae, Phoxocephalidae, Pleustidae, Podosiridae, Pontogeneiidae, Stegocephalidae, Stenothoidae (suborder Gammaridea), Podoceridae, Ischyroceridae, Aoridae and Calliopiidae (suborder Senticaudata) (Vinogradov 1995; Bellan-Santini and Thurston 1996; Desbruyères et al. 2001; Myers and Cunha 2004; Bellan-Santini 2005, 2006, 2007; Tandberg et al., 2012). Most species were described from the Lucky Strike vent field (see Table 1).

Up to now, no amphipod was mentioned from the TAG vent field according to the literature (Rona et al. 1986; Vinogradov 1995; Gebruk et al. 1997; Copley et al. 1999, 2007). During the oceanographic cruise BICOSE partly dedicated to the study of the background non-vent fauna of the TAG field, a strange amphipod was first discovered on video recordings, hung on masts fixed on basalt rocks. Two specimens were subsequently sampled with a remotely operated vehicle (ROV) slurp gun and then identified as a new species belonging to family Dulichiidae and genus Dulichiopsis, so far never mentioned from hydrothermal vent areas (see Table 1). Erected by Myers and Lowry (2003) from the sub- family Dulichiinae Laubitz, 1983, this family currently comprises six genera (Rauschert 1990; Horton et al. 2016): Dulichia Krøyer, 1845 (6 spp.); Dyopedos, Spence Bate 1857 (9 spp.); Paradulichia Boeck, 1871 (2 spp.); Dulichiopsis, Laubitz, 1977 (7 spp.); Paradyopedos Andres \& Rauschert, 1990 (1 sp.); Pseudodulichia Rauschert, 1990 (1 sp.). Created by Laubitz (1977), the genus Dulichiopsis belongs to the group of genera (with Dulichia and Pseudodulichia) characterised by a facial row of setae on the inner plate of maxilla 2. Dulichiopsis can be distinguished from Pseudodulichia by the eyes (abnormal in Dulichiopsis versus well developed in Pseudodulichia), the dactylus of the maxillipedal palp (elongate and pointed versus short and blunt) and the number of oostegites (3 pairs versus 4 pairs); from Dulichia by the eyes (abnormal in Dulichiopsis versus well developed in Dulichia), the dactylus of the maxillipedal palp (elongate and pointed versus short and blunt) and the palm on pereopod 5-7 propodus (present versus absent) (data from Laubitz 1977; Hirayama and Takeuchi 1993; Rauschert 1988, 1990). According to Lowry et al. (2010), the genus Dulichiopsis is one of the most speciose within the family Dulichiidae, with seven described species: D. abyssi (Stephensen, 1944); D. barnardi Laubitz, 1977; D. brevidactyla Ledoyer, 1986; D. cyclops (Gurjanova, 1946); D. macera (G.O. Sars, 1879); D. nordlandica (Boeck, 1871); D. remis (J.L. Barnard, 1964). All these Dulichiopsis are mainly deep-sea species (depth range: 183$3229 \mathrm{~m}$ ), widely distributed in the N Atlantic, N Pacific and Arctic Oceans, as well as in the Indian Ocean (N Madagascar).

The present study describes the morphological traits of this new dulichiid species, coupled with in situ observations on its behaviour and lifestyle recorded in the vicinity of the TAG vent fields (at about $3500 \mathrm{~m}$ depth).

\section{Materials and methods}

The oceanographic cruise BICOSE (January-February 2014) was dedicated to multidisciplinary studies at the hydrothermal vents Snake Pit and TAG from the Mid-Atlantic Ridge, with a special focus on inactive areas as well as on surrounding areas out of hydrothermal influence. In situ observations and samplings of the fauna have been carried out within the TAG hydrothermal area thanks to the ROV Victor 6000 . Figure 1 shows the location of the different observation sites during dives PL570, PL573 and PL575. The two specimens herein studied have been sampled during dive PL573 with the slurp gun of the ROV (sample code: Aspi $1 ; 26^{\circ} 08^{\prime} 15.09^{\prime \prime} \mathrm{N}, 44^{\circ} 49^{\prime}$ $31.88^{\prime \prime} \mathrm{W}, 3651 \mathrm{~m}$ depth, 02 February 2014). Body parts and dissected appendices were permanently mounted on slides in dimethyl hydantoin formaldehyde (DMHF) medium and drawings have been made with a camera lucida attached to a compound microscope OLYMPUS SZ40. The body length 
Fig. 1 a Geographical location of the TAG hydrothermal vent field (triangle; $3650 \mathrm{~m}$ depth) on the northern Mid-Atlantic Ridge. b Observation sites (white dots) of Dulichiopsis dianae sp. nov. in the TAG vent field during dives PL570 (sites 1 and 2, 28/01/ 2014), PL573 (sites 3 and 4, 02/ 02/2014) and PL575 (sites 5, 04/ $02 / 2014$ ) of the remotely operated vehicle (ROV) Victor (BICOSE cruise, 10 January-11 February 2014). The holotype and paratype herein examined have been collected at site 3 during dive PL573
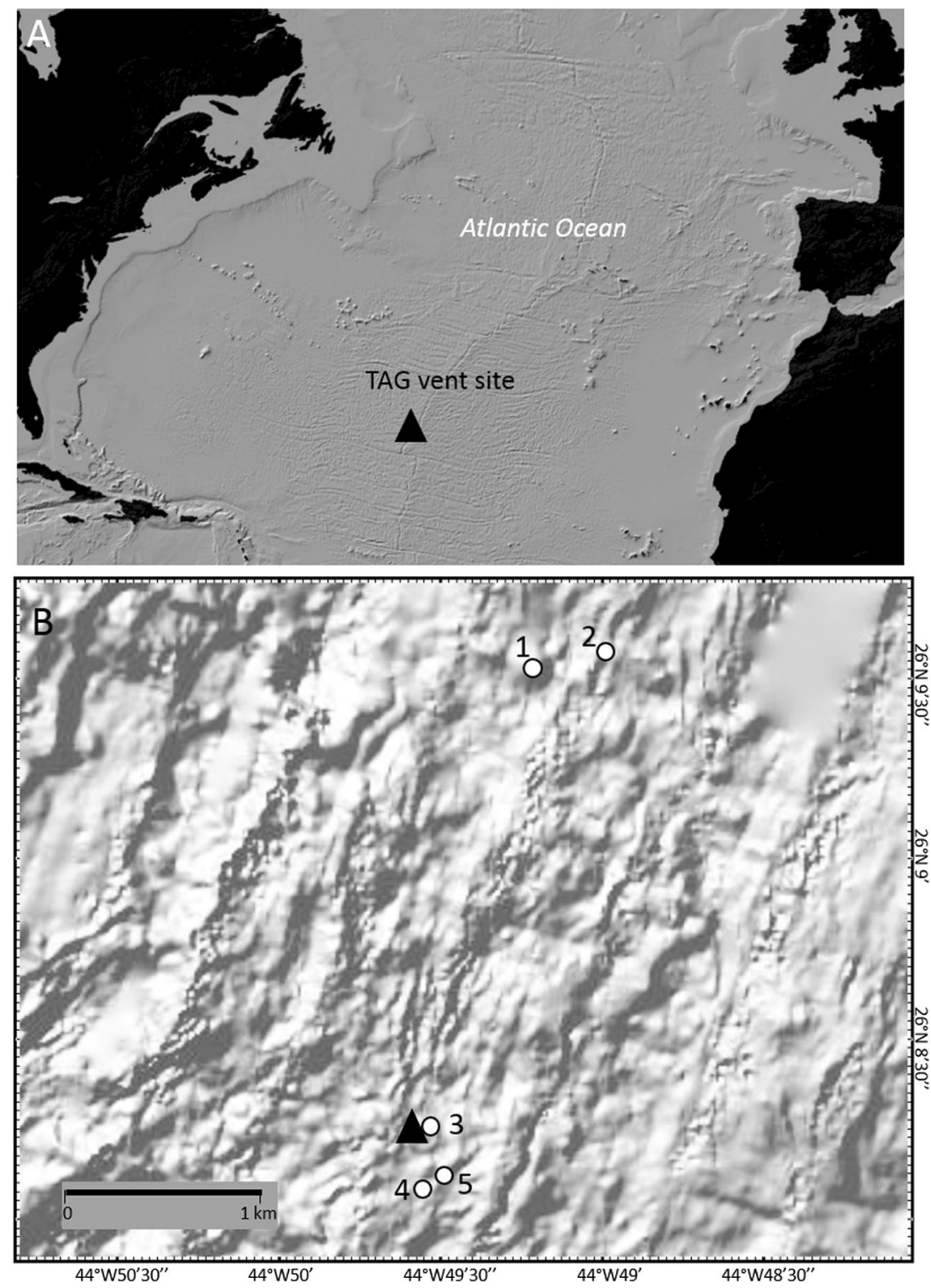

(BL) was measured on manually extended specimens, between the head anterior margin and telson tip. Figure abbreviations: HD: head; A1, A2: antenna 1, 2; LB: labrum; MD: mandible, MXP: maxilliped; G1, G2: gnathopod 1, 2; P3-6: pereopods 3-6; PL1: pleopod 1; UR: urosome; T: telson; F: female; L: left; R: right. The holotype and paratype are deposited at the Muséum National d'Histoire naturelle (MNHN), Paris.

\section{Results}

\section{Systematics}

Order Amphipoda Latreille, 1816

Suborder Senticaudata Lowry \& Myers, 2013

Infraorder Corophiida Leach, 1814
Parvorder Caprellidira Leach, 1814

Superfamily Caprelloidea Leach, 1814

Family Dulichiidae Dana, 1849

Genus Dulichiopsis Laubitz, 1977

Dulichiopsis dianae sp. nov. (Figs. 2, 3, 4 and 5)

Material examined. Holotype, mature female, $\mathrm{BL}=$ $7.2 \mathrm{~mm}$ (MNHN-IU-2013-18758). TAG hydrothermal vent field, BICOSE cruise, 02 February 2014, PL573, 26 ${ }^{\circ} 08^{\prime}$ $15.09^{\prime \prime} \mathrm{N}, 44^{\circ} 49^{\prime} 31.88^{\prime \prime} \mathrm{W}, 3651 \mathrm{~m}$ depth, sampled with the ROV slurp gun, rocky substrate. Paratype: 1 mature female, $\mathrm{BL}=5.8 \mathrm{~mm}$ (MNHN-IU-2013-18759). Same data as for the holotype. Specimens damaged due to the sampling method (aspiration).

Type locality. TAG hydrothermal area, Mid-Atlantic Ridge.

Etymology. Dedicated to Diana R. Laubitz (Canadian Museum of Nature, Ottawa) in recognition of her outstanding 
Fig. 2 Dulichiopsis dianae sp. nov. a On-board picture of the female specimen (holotype, MNHN-IU-2013-18758) collected during dive PL573, showing its damaged condition after aspiration by the slurp gun of ROV Victor. b Habitus of the holotype specimen MNHN-IU2013-18758 (drawn by J.-F. Dejouannet)
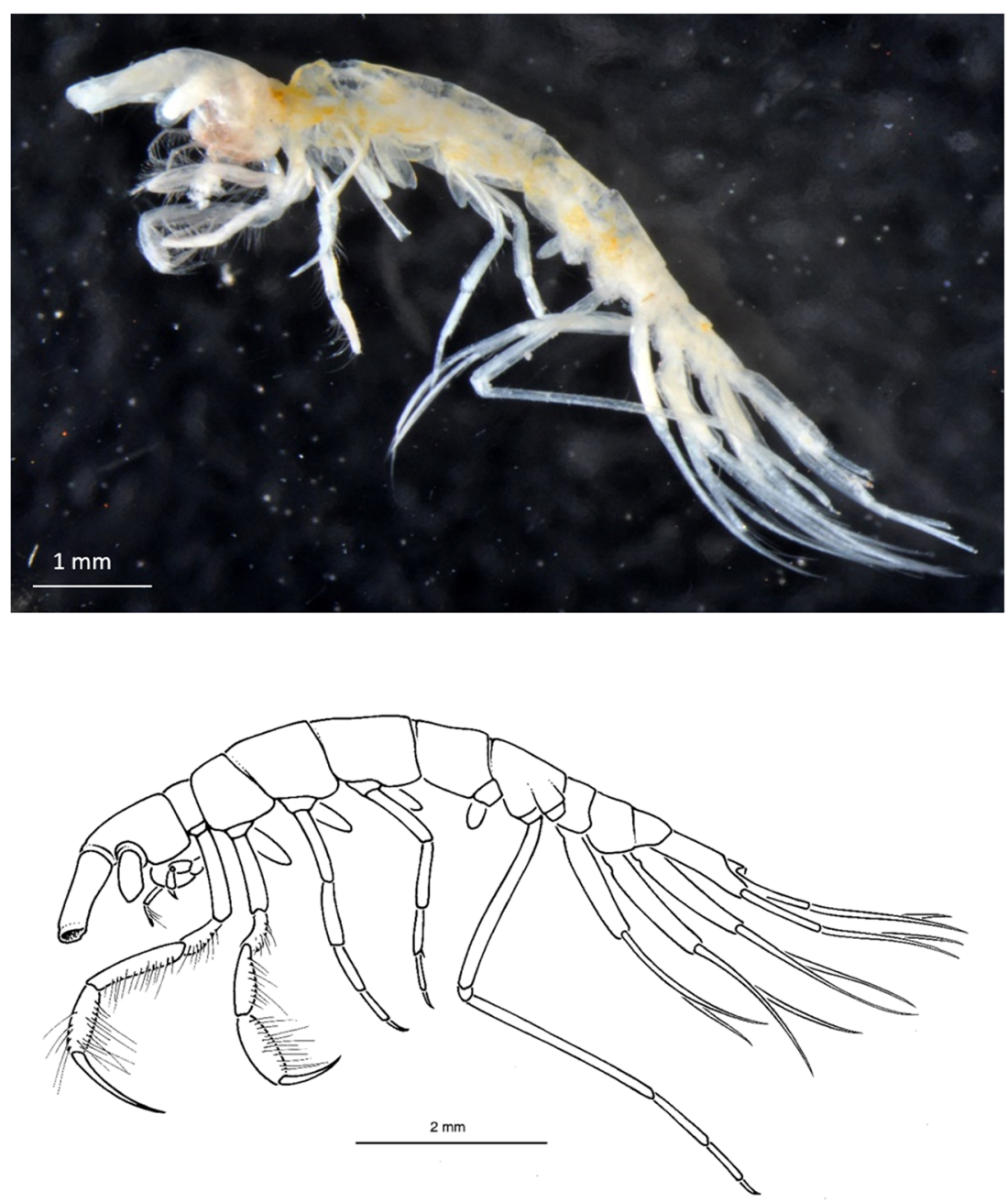

contribution to amphipod taxonomy and her revision of podocerid amphipods. She created the genus Dulichiopsis (Laubitz, 1977) within the family Dulichiidae.

\section{Description of holotype and paratype females}

Body: Elongate, cylindrical. Head longer than pereonites 1-2, eyes absent but presence of white pigment along head anteroventral margin (observed on fresh specimens). Pereon smooth, very long and slender, pereonites 6-7 fused; coxae small and distinct; coxal gills present on pereonites $2-5$. Pleon 3 -segmented. Urosomal segments sub-equal to pleon. Urosomite 1 longer than urosomite 2. Antenna 1-2: both broken, only first peduncle article present. Labrum: broad, bilobed at apex, no setation on distal part. Mandible: well developed, with large molar; incisor strongly toothed, left lacinia mobilis toothed, right lacinia mobilis finely denticulate; setal row with 3 setae; palp with three articles, article 1 shortest, article 2 longer than article 3, both with plumose setae. Maxilla 1: outer plate with 6 distal long stout setae (probably more numerous but some of them lost), inner plate simple, maxillary palp broken. Maxilla 2: with subapical row of plumose setae on inner plate; outer plate broader than inner plate, with a distal row of plumose setae. Maxilliped: palp 4articulate with long setae, article 4 long and slender, regularly tapering to distal end, with a long stout seta on distal part (broken on the left palp); inner plate with stout setae and plumose setae on distal margin; outer plate with outer margin regularly convex and apically rounded, inner margin with 6 short stout setae and 2 long stout setae on distal part. Gnathopod 1: simple; basis slender, without setae; carpus longer than propodus, with long plumose setae along posterior margin; prododus with long plumose setae on inner margin; dactylus curved, longer than propodus, with short simple setae on inner margin. Gnathopod 2: shorter than gnathopod 1; carpus slightly expanded posteriorly, sub-equal to propodus, with long plumose setae on posterior margin and outer face; propodus with at least 9 stout setae along palmar margin; dactylus slightly curved, with short simple setae on posterior margin. Pereopods 3-4: similar general shape, with basis not expanded (anterior and posterior margins parallel), merus enlarged, weak propodus and dactylus; basis with glandular 


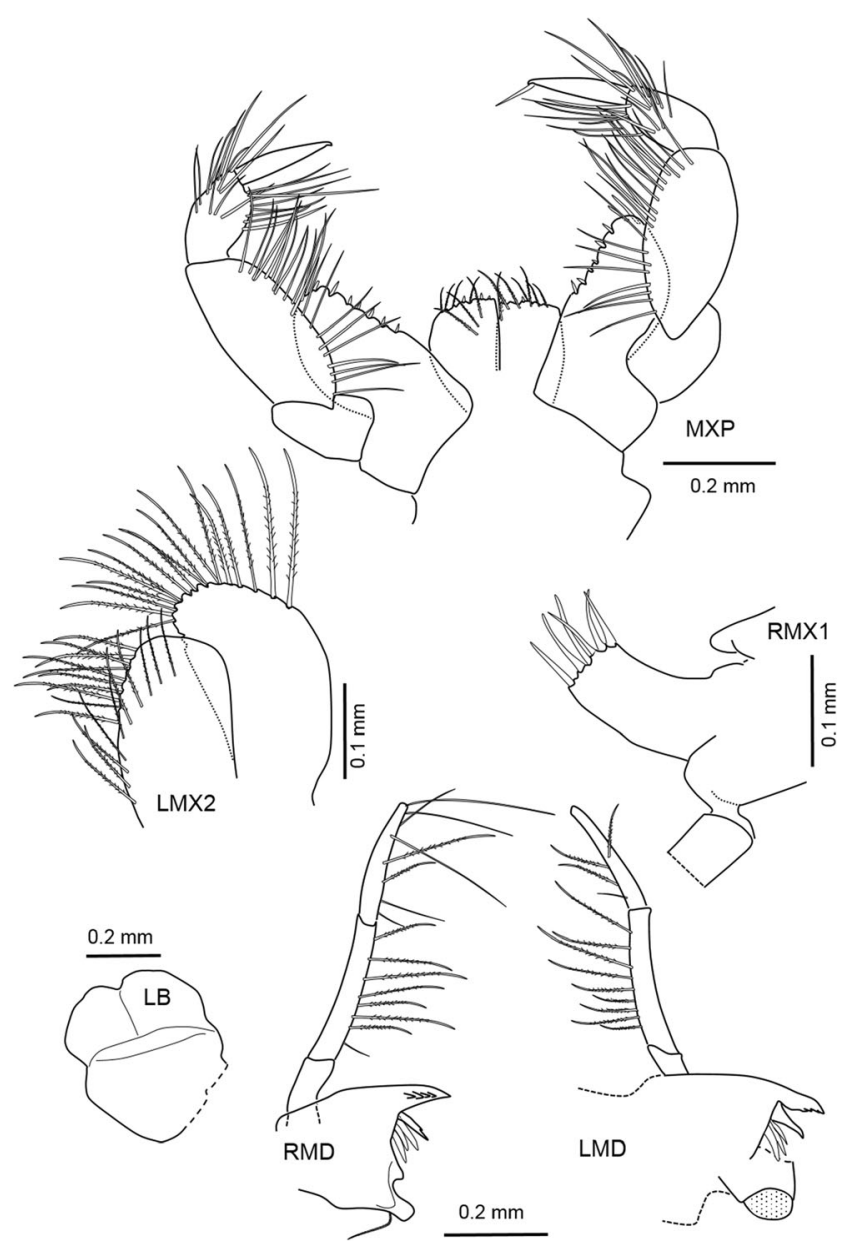

Fig. 3 Dulichiopsis dianae sp. nov. Holotype female (MNHN-IU-201318758). LB: labrum; LMD: left mandible; RMD: right mandible; RMX1: right maxilla 1, posterior face (maxillary palp broken); LMX2: left maxilla 2, posterior face; MXP: maxilliped, posterior face

tissues (well visible under cuticle), dactylus short, showing sub-apical depression with glandular opening ('glandular type' pereopod); pereopod 3 with basis longer than in pereopod 4; carpus of pereopod 4 with postero-subdistal stout curved seta. Pereopods 5, 7: lost in both specimens. Pereopod 6: prehensile; basis and merus elongate and slender; carpus longer than propodus; propodus palmar margin with short stout seta; dactylus approximately half the length of propodus and with denticulate posterior margin (not visible in Fig. 5). Pleopods 1-3: large, biramous, with strongly developed peduncle, one bifid coupling seta on inner side of peduncle. Uropods: uropods 1-2 very long and slender, uropod 3 absent; uropod 1 peduncle longer $(\times 1.5)$ than uropod 2 peduncle, rami with minute stout setae; uropod 2 shorter than uropod 1. Telson: small, trapezoidal and distally truncated.

Remarks: According to Laubitz's diagnoses and key (1983), the two specimens collected at TAG hydrothermal field doubtless belong to the family Dulichiidae and the genus Dulichiopsis, characterised by the following morphological characters: head more or less triangular; eyes absent;

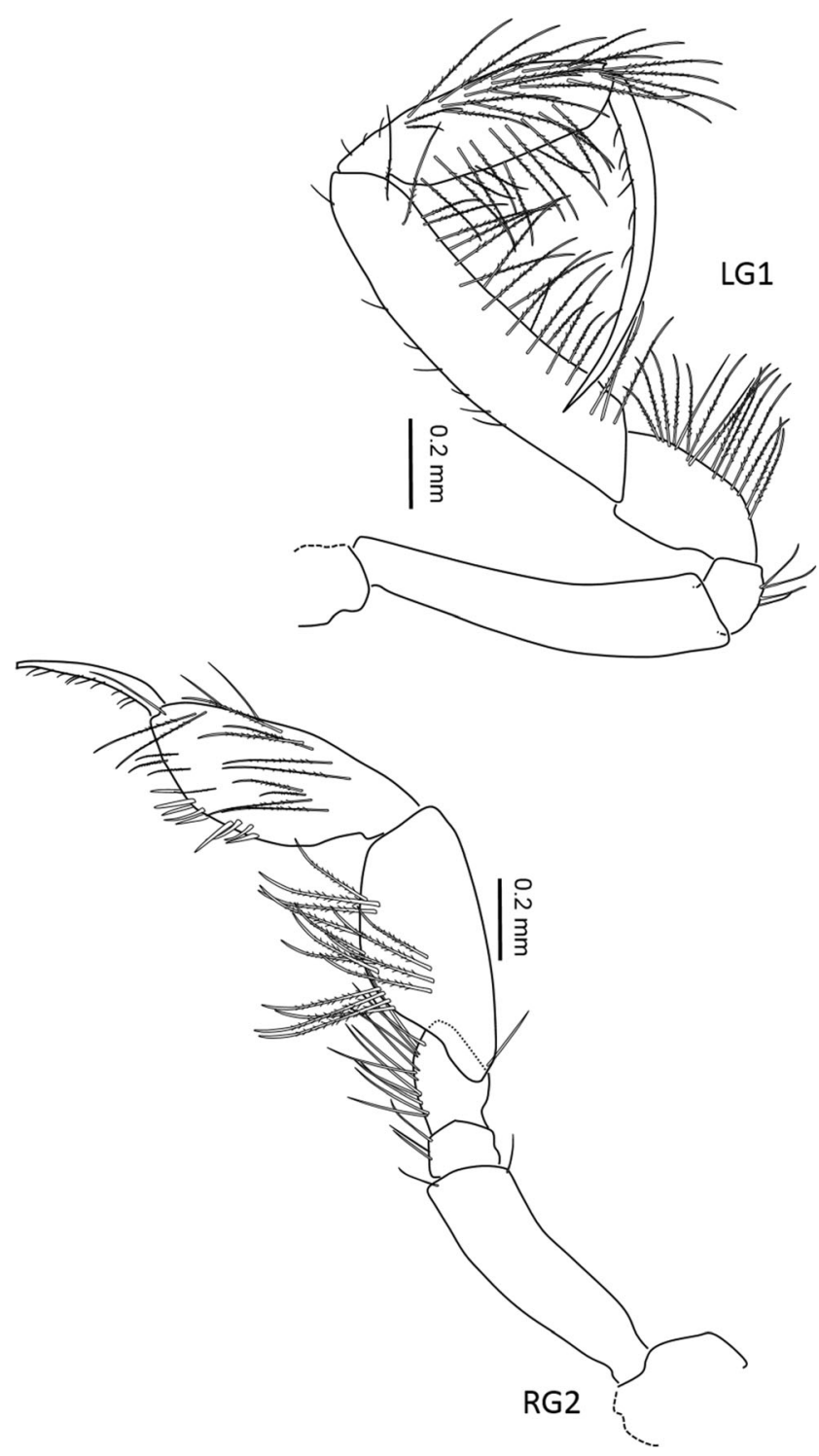

Fig. 4 Dulichiopsis dianae sp. nov. Holotype female (MNHN-IU-201318758). LG1: left gnathopod 1; RG2: right gnathopod 2

mandibular palp slender, sparsely setose; maxilla 2 inner plate with facial setae; maxilliped palp with long slender dactyl; pereopods 3-4 glandular, basis not greatly expanded; pereopods 5-7 with propodal palm; urosomite 1 longer than pleosomites $2+3$; uropods $1-2$ normal; gills on pereonites $2-5$. Unfortunately, these two specimens are female and, consequently, no males are available for morphological comparisons with other known Dulichiopsis species (male gnathopod 2 propodus is a valuable morphological feature for species identification). Furthermore, even with high-resolution images, males cannot be discriminated on video recordings and, consequently, a relevant morphological description of these individuals could not be performed. According to Laubitz's identification key (1977), the TAG specimens are morphologically very close to $D$. nordlandica (Boeck, 1871). A morphological comparison has been done with 


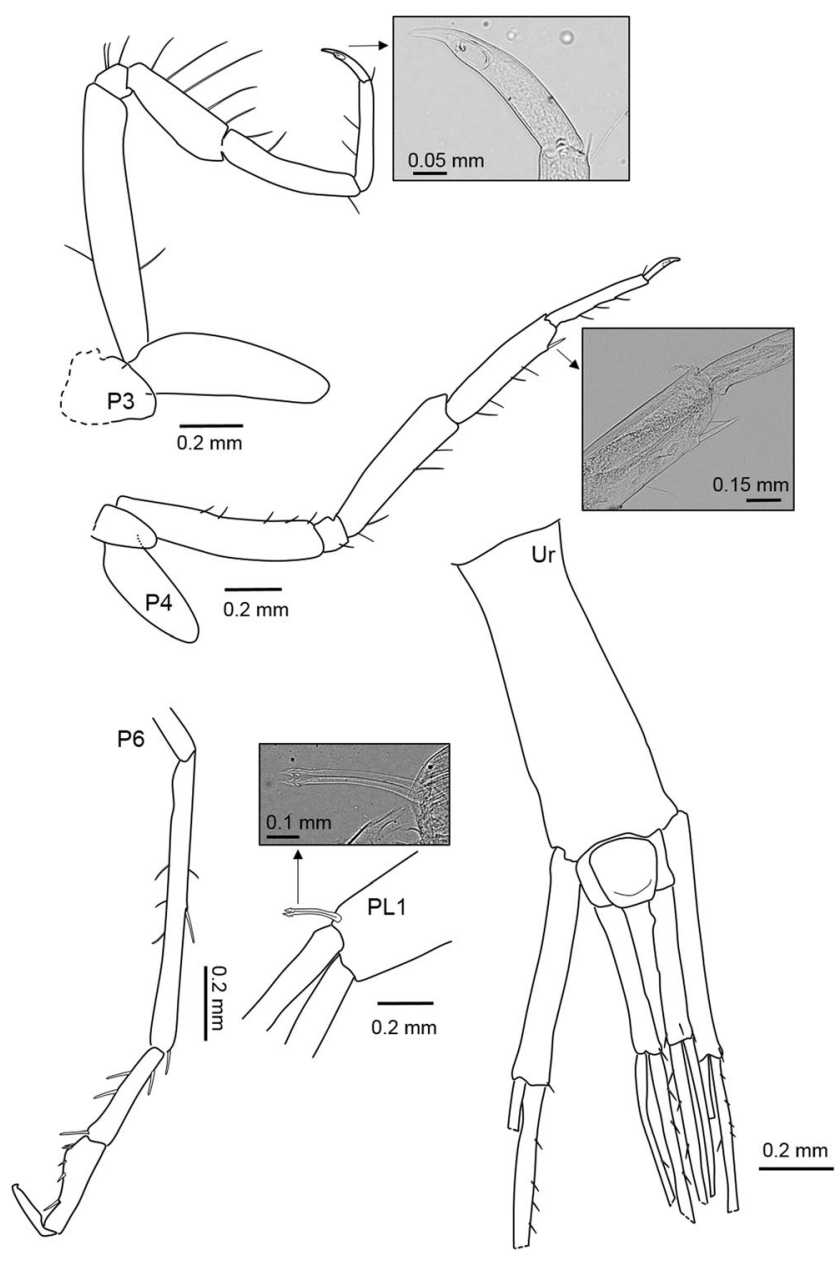

Fig. 5 Dulichiopsis dianae sp. nov. P3-4, P6, PL1: holotype female (MNHN-IU-2013-18758); UR: paratype female (MNHN-IU-201318759). LP3: left pereopod 3, outer face. Photo: detail of dactyl, showing a small distal oval depression with a glandular opening. RP4: right pereopod 4, outer face. Photo: detail of propodus, showing the subdistal stout seta on its posterior margin. RP6: right pereopod 6 . RPL1: right pleopod 1. Photo: detail of peduncle, showing the shape of the coupling seta on its inner margin. UR: urosomite $1-2$, telson and corresponding uropods (rami apically damaged), dorsal view

D. nordlandica specimens (reference ZMUC-CRU-7344) collected during the Thor expedition (Danish Skagerrak, St 285, $660 \mathrm{~m}, 14 / 10 / 1904)$. Dulichiopsis dianae sp. nov. differs from $D$. nordlandica by the presence of a postero-distal curved stout seta on its $\mathrm{P} 4$ carpus (females; not known in males of both species) and by its truncated telson (versus rounded distally in $D$. nordlandica).

\section{Identification key of Dulichiopsis species}

(modified from Laubitz, 1977)

1 - Eyes fused, forming single dorsal eye................................. cyclops (Gurjanova, 1946)

Arctic Ocean (off N Siberia); 2500 m

- Eyes, if present, lateral and rudimentary..................2

2- Uropod 2 outer ramus less than half the length of the inner ramus D. brevidactyla Ledoyer, 1986

Indian Ocean (NE Geyser Bank); 2500 m
- Uropod 2 outer ramus at least as long as half the length of the inner ramus....

3- Uropod 2 outer ramus obviously more than half the length of the inner ramus; stout setae not clustered on posterior margin of female gnathopod 2 propodus.

...4

- Uropod 2 outer ramus just half the length of the inner ramus; median cluster of stout setae on posterior margin of female gnathopod 2 propodus.

4- Head no longer than pereonite 2; urosome shorter than pleosome; female gnathopod 2 propodus with proximal row of stout setae on posterior margin (including part of the palm); male gnathopod 2 dactylus without proximal knob and thickened medially. D. macera (G.O. Sars, 1879)

N Atlantic Ocean; Arctic Ocean; 498-2886 m

- Head longer than pereonite 2; urosome at least as long as pleosome; female gnathopod 2 propodus with row of stout setae on proximal palmar margin; male gnathopod 2 dactylus evenly tapered with proximal knob*

*: not known in $D$. dianae

5- Head blunt anteriorly; pereonites 6-7 longer than pereonite 5 , which is equal to pereonite 4 ..D. remis (J.L. Barnard, 1964)

N Pacific Ocean; 800-882 m

- Head pointed anteriorly; pereonites 6-7 sub-equal to or shorter than pereonite 5 , which is shorter than pereonite 4

6- Telson distally rounded. Pereopod 4 carpus without stout subdistal seta on posterior margin..............D. nordlandica (Boeck, 1871)

N Atlantic Ocean; Mediterranean; 183-2258 m

- Telson distally truncate. Pereopod 4 carpus with stout subdistal seta on posterior margin.........D. dianae sp. nov.

N Atlantic Ocean (Mid-Atlantic Ridge); 3635-3651 m

7- Urosome no longer than pleosome; head blunt anteriorly; gills short and stout ......................... abyssi (Stephensen, 1944)

N Atlantic Ocean (off E and W Greenland; off Cape Cod); $<1000-3229 \mathrm{~m}$

- Urosome noticeably longer than pleosome; head pointed anteriorly; gills long and slender ... D. barnardi Laubitz, 1977

N Pacific Ocean; $882 \mathrm{~m}$

\section{Ecology of D. dianae sp. nov.}

\section{Distribution and abundance of Dulichiopsis stems}

Dulichiopsis dianae sp. nov. has been randomly observed during dives PL570, PL573 and PL575, mainly dedicated to the exploration of inactive areas around the TAG active vent site (Fig. 1). The first observation of this species during PL570 was initially not very well interpreted, described as "mysterious creatures swinging on a stem" in the corresponding dive 
log. After a careful re-examination of the video recordings, they were finally identified as dulichiid amphipods, securely attached to stem-like structures by their posterior pereopods. The subsequent dives have focussed on the search of these epibenthic organisms and, during dives PL573 and PL575, close-up video observations could be dedicated to their strange behaviour on specific sites of the sea floor. Within the TAG hydrothermal field, these observation sites were always located at some distance from the closest active events (see Fig. 1): $60 \mathrm{~m}$ for sites 3-4 (PL573), $240 \mathrm{~m}$ for site 5 (PL575) and $2.5 \mathrm{~km}$ for sites 1-2 (PL570). Even at site 3 (the closest to an active event), no hydrothermal activity could be visually observed on video recordings (i.e. diffusion of warm shimmering vent fluid). The dulichiids were first detected thanks to their whitish stem support (not collected with the ROV slurp gun), which was fixed on darker hard bottoms corresponding to scree slopes of basaltic rocks (Fig.6). At site 3 , video recordings also show the presence of thin scattered spots of sediments with a red-orange colouration, indicative of a sulphur hydrothermal origin and resulting from the deposition of mineral particles transported by vent plumes (see supplemental data, video recordings). The thin and flexible stems are mainly attached on the sides of rock blocks (rarely on their top), more or less horizontally, suggesting a preferential disposition with respect to bottom currents. Their length ranges from 5 to $7 \mathrm{~cm}$, with a diameter of about $0.6 \mathrm{~mm}$ in their distal part (estimations from video recordings), clearly thicker in their basal part and expanding at their attachment to the substratum. In non-active hydrothermal areas, these stems have a patchy distribution and their abundance is difficult to estimate from video recordings (maximum of about 16 stems per $\mathrm{m}^{2}$ in a sequence from site 3 ).

\section{Lifestyle and behaviour of $D$. dianae sp. nov. (Fig. 6; see supplemental data)}

The best close-up video observations on the behaviour of D. dianae sp. nov. have been recorded on sites 3 and 5 (Fig. 1). In most cases, two individuals, as a couple, were installed on the same stem, one of them positioned distally or subdistally and the other one at a lower location, both of them showing the same posture (Fig. 6). As the sex of these individuals cannot be recognised on video recordings, the sexual composition of each pair remains unknown. In a few cases, only one individual was present on a stem. No specimen was observed to be free on the bottom (not attached to a stem). The powerful morphology of the three pairs of pleopods (see Fig. 2 ; a genus feature) suggests that this species is a good swimmer, although not actually verified on video recordings. All individuals observed on the stems showed nearly the same size (adults) and small-sized juveniles have not been observed in this habitat at the time of this survey. The behaviour of the observed individuals can be categorised as follows: (i)

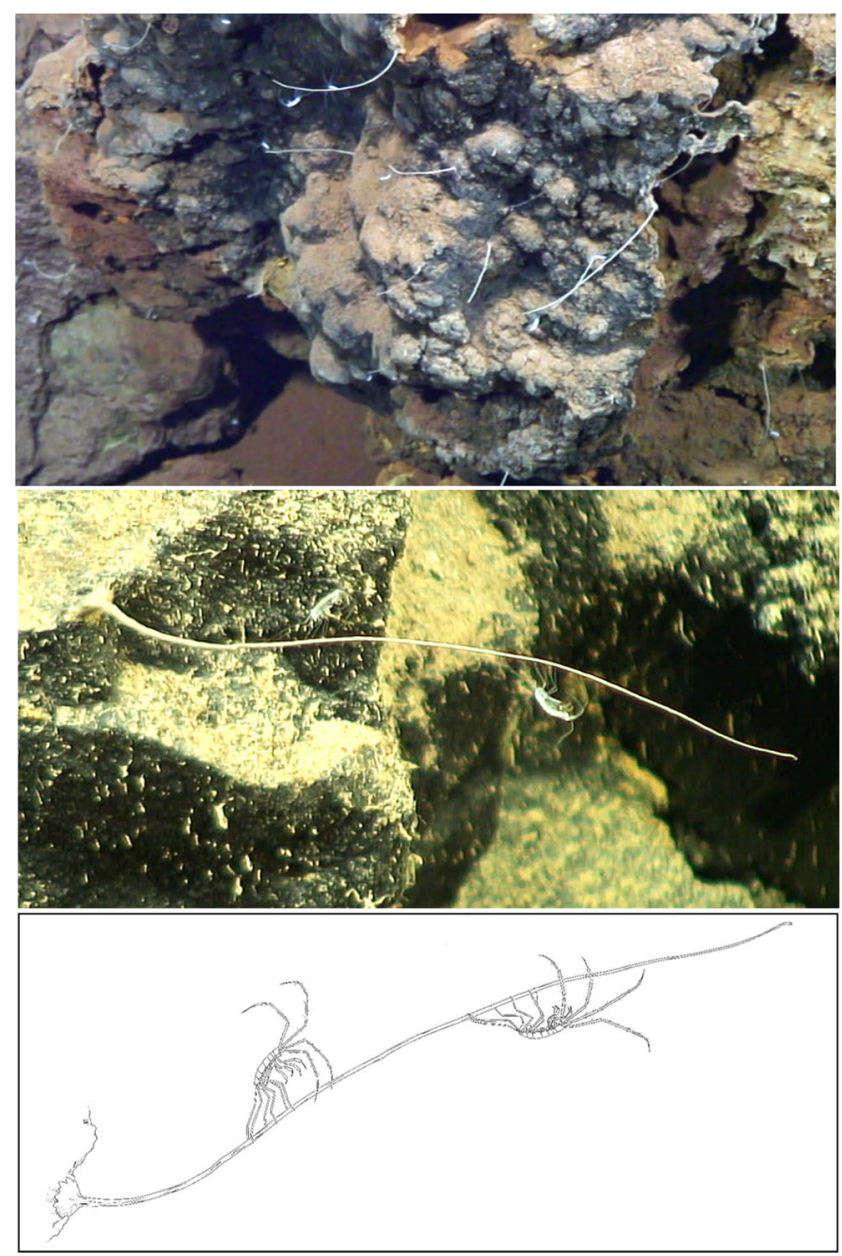

Fig. 6 a In situ picture of a rocky bottom (basalt covered by a thin layer of sediments) taken by ROV Victor during dive PL573, showing the distribution and abundance of masts in the TAG hydrothermal vent field. b In situ living position of two specimens of $D$. dianae sp. nov. on their mast (dive PL575). c Artistic reconstitution showing the resting position of two specimens on their mast, with the full deployment of their antennae 1 and 2 in the near-bottom current (filter feeding attitude)

stationary posture; (ii) cleaning and feeding; (iii) displacement along the stem. Each individual in a stationary posture is hooked to the stem by its long and prehensile pereopods 5-7 (propodus/dactylus clamp). Its head is oriented towards the free end of the stem, its body is in a more or less erected position at some distance from the stem (angle of ca. $45^{\circ}$ between the body axis and stem) and its urosome/pleosome body section (the so-called 'abdomen' according to Laubtiz 1979) is folded under its mesosome (posterior part of urosome approximately reaching the basis of pereopod 4). Its two pairs of antennae are deployed in a 'star' position, i.e. in a more or less perpendicular position to the body axis, slightly curved backwards by near-bottom currents, probably in order to favour the collection of suspended particles in the surrounding water. As antennae of the collected specimens were lost, the setose condition of these appendages (not visible in video recordings) remains unknown in this species. However, they 
are probably heavily setose, as is the case for most Dulichiopsis species according to habitus descriptions [see Sars' (1895) drawings in the case of D. nordlandica]. Surprisingly, all the observed stems show a whitish aspect (similar to the body colour of amphipod specimens), in contrast with the more colourful surrounding bottoms (from grey for basaltic rocks to yellow for sulphidic sediments), suggesting that such erected supports are not built with local sediment particles (no stem collected in this study). Furthermore, according to video recordings, stems are patchily distributed on the sea floor and show a great flexibility in response to near-bottom currents. According to video recordings, the relatively short pereopods 3-4 are not involved in the hooking posture and are positioned along the amphipod body. As yet mentioned in the morphological description of this species, light microscopy observations of these appendices revealed the presence of supposed glandular tissue in their basis and carpus (Fig. 7a, b), different from a classical muscular tissue. Moreover, as shown in Fig. 5, the dactylus of pereopods 3-4 clearly shows a distal elliptical depression with a more or less visible small distal opening. Such a peculiar morphology suggests that both pairs could be involved in a process of mucus synthesis, probably used in stem building. However, the actual implication of pereopods 3-4 in this building process is not known. As observed, the setose gnathopods 1-2 are involved in the grooming of both pairs of antennae, a feeding mechanism allowing the recovery of nutritive particles collected by these appendages in the near-bottom water environment (see the video recordings in the supplemental data, at timings 33 and $118 \mathrm{~s})$.

The stationary posture of individuals was observed during most of the duration of video sequences. However, in the close-up sequences (see the video recordings in the supplemental data) along-stem displacements were noticed in the case of individuals forming a pair on the same stem. The individual in the upper position goes down along the stem to reach its lower associate, climbing along the stem with its pereopods 5-7 in a backward movement (no change from the initial body orientation). After some body contact between the two partners during the course of a few seconds (involving gnathopods, maybe for the transfer of nutritive particles), the moving individual goes back to its initial upper position. The total duration of these observed round trips is short, ranging between 60 and $80 \mathrm{~s}$. A similar displacement of the lower individual towards the upper one has not been observed in video recordings.

\section{Discussion}

\section{Adaptative strategy in Dulichiidae}

Dulichiopsis dianae sp. nov. is the eighth known species of the deep-sea genus Dulichiopsis and the only species discovered in the vicinity of hydrothermal vents. It is the deepest species known for this genus (3635-3651 m; see identification key). According to the present video observations (see the supplemental data), the current knowledge about the ecology and behaviour of $D$. dianae sp. nov. can be summarised as follows: (i) occurrence on inactive vent areas at a minimal distance of $60 \mathrm{~m}$ from an active chimney; (ii) most specimens arranged in pairs, each pair hooked on a long and flexible stem fixed on basaltic rocks; (iii) most specimens in a 'wait and see' stationary posture on their stem, facing the near-bottom current and transversally deploying both pairs of antennae apparently to collect suspended particles transported by the bottom currents. Such behaviour including self-constructed stems seems to be an original trait of some Dulichiidae. It was already described in various coastal species, such as Dulichia falcata (Spence Bate, 1857), D. rhabdoplastis McCloskey, 1970, Dyopedos monacanthus (Metzger, 1875) and D. porrectus Spence Bate, 1857 (see McCloskey 1970; Laubitz 1977, 1979; Moore and Earll 1985; Mattson and Cedhagen 1989; Meyer-Rochow et al. 1991; Thiel 1997, 1998). Reversely, it has, so far, never been mentioned in other Dulichiopsis species, although their similar morphology with

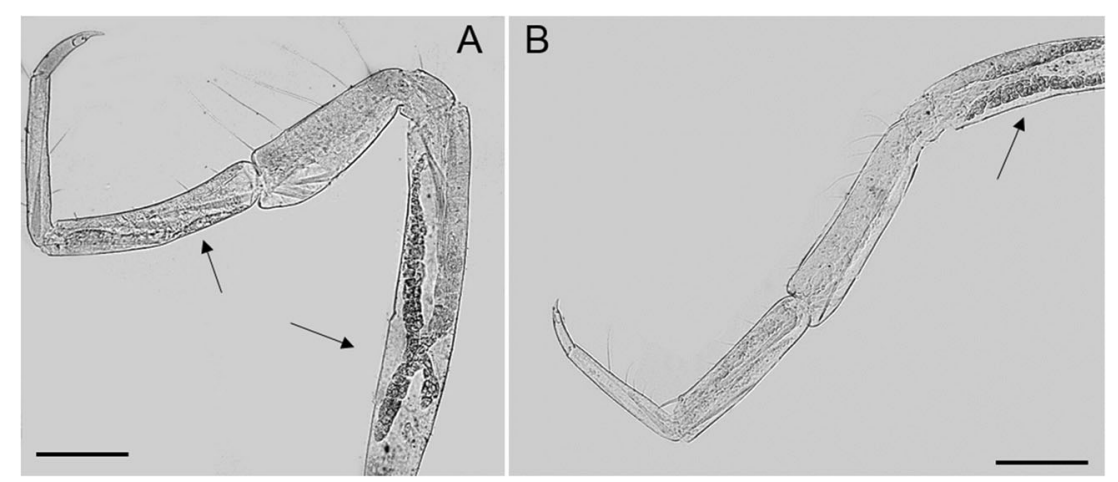

Fig. 7 Dulichiopsis dianae sp. nov. Holotype female (MNHN-IU-201318758). a, b Elongate glandular organs (arrows) located within the basis of the left pereopods 3 and 4, respectively. Although without apparent connection, it is likely that the glandular production (mucus) is rejected from the appendage by a functional opening located on the oval subdistal depression of the dactylus (see Fig. 5). Scale bars $=0.2 \mathrm{~mm}$ 
D. dianae sp. nov. (long and setose antennae, glandular pereopods $3-4$, long and prehensile pereopods 5-7) strongly suggests the same kind of behaviour in these species as herein observed. This is probably caused by a misinterpretation of isolated stems haphazardly present in benthic samples, wrongly classified as unidentified rod-shaped detritus.

In stem-builder dulichiids, stems are fixed on sessile hydroids (D. porrectus; Moore and Earll 1985), on spines of mobile sea urchins (D. rhabdoplastis; McCloskey 1970), on solid objects from surficial sediments (Dyopedos spp.; Mattson and Cedhagen 1989) or on basaltic rocks (D. dianae sp. nov.; this study). The length of $D$. dianae sp. nov. stems $(5-7 \mathrm{~cm}$; estimated from video recordings) falls within the upper range of values mentioned for other dulichiids: $<2-4 \mathrm{~cm}$ for D. rhabdoplastis (McCloskey 1970); $2.5 \mathrm{~cm}$ (juveniles) and 5-8 cm (adult females) for Dyopedos spp. (Mattson and Cedhagen 1989); up to $9.1 \mathrm{~cm}$ (adult females) for D. monacanthus (Thiel 1998). Moreover, this last author mentioned a strong positive correlation between stem lengths and size of parental females in D. monacanthus.

Although the stem-building process remains unknown in the case of $D$. dianae sp. nov., it has been more or less thoroughly described in the case of several shallow-water dulichiids. Such a behaviour was described for the first time by McCloskey (1970) for $D$. rhabdoplastis from in situ observations. Fixed on spines of the sea urchin Mesocentrotus franciscanus (A. Agassiz, 1863), rods are built up with the own faeces of the amphipod, manipulated with its maxillae and maxillipeds, and, finally, cemented by oral secretions at the tip of the mast in construction. Mattson and Cedhagen (1989) described in great detail the stem-building process in Dyopedos spp. (D. monacanthus and D. porrectus) raised in an aquarium. Gnathopods 1-2 secrete threads of mucus used in the preliminary phase of stem-building. Glandular pereopods 3-4 secrete permanent spinning threads and are used primarily for stem finishing. These threads change into amorphous mucus on application to the stem. Preferentially, the base of a stem is founded on a solid object beneath the sediment surface. Then, this base is prolonged upwards step by step, by the addition of seston or bottom material (sediment, faecal pellets) collected with gnathopods and cemented with spinning threads. A complete mast may be made in a few hours, but, this time strongly depends on environmental conditions (bottom currents). The finished stem is a firm, flexible, slightly tapering rod with a circular cross-section and an irregular swelling at its thicker end. Moore and Earll (1985) studied the stems of $D$. porrectus by scanning electron microscopy. They appear to be built up as a wound spiral with a longitudinal edge apparent over much of their length. Their external surface is covered in a fine meshwork of micro-fibrils ( 0.2 $0.3 \mu \mathrm{m}$ in diameter), presumed to be stretched silk secretions emanating from a terminal pore (ca. $1 \mu \mathrm{m}$ in diameter) of pereopod 3 dactylus. They concluded that such a structure, reminiscent of the geodetic construction of an aircraft fuselage, would confer relative strength together with flexibility to these stems. In the case of $D$. dianae sp. nov., it was not possible to observe the stem-building process on in situ videos but only the standing/cleaning behaviour of individuals on their stem. However, the morphological observations of pereopods 3-4 have revealed the presence of glandular tissues along their basis and carpus, as well as 'glandular dactyls' (with glandular opening). It seems likely that $D$. dianae sp. nov. should adopt the same method of stem-building as the aforementioned Dyopedos and Dulichia species. Laubitz $(1979,1983)$ stated that stem-building is a typical behaviour of the 'Dulichia' group (now erected as Dulichiidae), because species of this group are characterised by glandular pereopods 3-4. Most of them (except Dyopedos species) also possess prehensile pereopods 5-7 (with propodal palm), obviously used for the hanging of individuals on a stem/support. That is the case of all known Dulichiopsis species as well as the two Antarctic species Paradyopedos antarcticus Andres \& Rauschert, 1990 and Pseudodulichia antarctica Rauschert, 1990, although none of them are, so far, mentioned as stem builders.

As first hypothesised by Moore and Earll (1985), the stem function is a means of elevation for promoting feeding. This is an advantage for suspension-feeding species due to the fact that the speed of water currents and, consequently, the intensity of nutritive particle flow increase with the distance from the bottom. We can suggest that the stem-building behaviour is typical of the dulichiid group as indirectly underlined by Laubitz $(1979,1983)$ by indicating that the presence of glandular pereopods distinguishes dulichiids from podocerids. Among Dulichiidae, the Dyopedos genus with inflated and glandular pereopods 3-4 and non-prehensile pereopods 5-7 appears to be the most primitive (Laubitz 1979). The reduction of the length of pereopods 3-4 and the elongation of pereopods 5-7 with the subsequent development of a propodal palm (prehensile pereopods) represent another evolutive lineage leading to Dulichia and Dulichiopsis, grouping, respectively, intermediate and deep taxa in this family. It seems that the feeding strategy of Dulichiopsis species, even if based on similar patterns, is characterised by an important elevation above the substratum and a fixation of the stems on the sides of rock, at several centimetres above the bottom, as observed in situ for $D$. dianae sp. nov. Moreover, the elongation of pereopods 5-7 could be interpreted as another adaptation for promoting the position of the body far from the stem and, by consequence, far away from the bottom. A comparable behaviour has been already observed in some deep-sea taxa, such as in the case of the Caprellidae Parvipalpus major Carausu, 1941, characterised by a body elongation interpreted as a key adaptation to deep-sea environments (Corbari et al. 2005). Considering the available biological data on the 
different dulichiid genera, it can be concluded that the family Dulichiidae is characterised by its stem-building behaviour for promoting suspension feeding.

\section{Endemism and the designation of 'hydrothermal species'}

It is hardly difficult to find in the literature the exact definition of a 'vent species' or 'hydrothermal species'. However, this terminology has been largely used for amphipods collected in the vicinity of hydrothermal vents (see review in Table 1), although it is sometimes difficult to find in the corresponding literature where they were actually sampled with respect to hydrothermal vents. In the present study, we consider that $D$. dianae sp. nov. is not a hydrothermal species because our few observations show that it occurs between $60 \mathrm{~m}$ and $2.5 \mathrm{~km}$ from the TAG active vent site. From these observations, the following questions arise: what is the definition of a hydrothermal/vent species? What are the main criteria to be used for distinction from the background fauna? Are they characterised by their endemism, abundance, rarity, nutritional patterns or even by their special adaptations, such as bacterial symbiosis? It is obvious that 'true' vent species do exist, such as the polychaetes Riftia pachyptila Jones, 1981 and Alvinella pompejana Desbruyères \& Laubier, 1980 or even the crustacean Rimicaris exoculata Williams \& Rona, 1986, all living in close contact with hydrothermal vents. Considering the amphipods (see Table 1), some of them can actually be considered as vent species because of their abundance or their trophic relationships, such as Ventiella sulfuris, Halice hesmonectes, Bouvierella curtirama and Luckia striki. The other amphipods mentioned in Table 1 are represented by a few occurrences, few specimens (sometimes a single known specimen), often without information about their actual habitat in these environments. More than underlining the excessive use of the expression 'vent species' for amphipods from hydrothermal areas, these observations highlight the bias in the perception of these environments by the scientific community. Since their discovery, they have been considered by default as original and extreme, without any consideration of a large deep-sea context. The problem is that this record of 'vent species' has contributed to the notion of high endemism in the hydrothermal environments (Tarasov et al. 2005; Wolff 2005; Desbruyères et al. 2006). Recently, Galkin and Sagalevich (2017) underlined that there are different opinions concerning the applicability of the term 'endemism' in the case of hydrothermal vents because of referring to a biotope and not to a geographical region. Instead of 'vent endemic', the term 'vent obligate' was proposed, which is defined as 'precisely restricted to a certain type of habitat' (Mironov et al. 2002). Moreover, they noticed that a large number of species (and higher taxa) which were initially described as 'endemic' from vents habitats could also be found in nonvent habitats as well as in background environments.

\section{Conclusions}

According to the data available for this study (collected specimens and in situ video recordings), many questions are still open. In the specific context of Dulichiopsis dianae, its social behaviour is still unknown, due to the non-discrimination of sexual identity of individuals on their stem and the apparent absence of juveniles at the time of sampling. For instance, no more comments can be provided about the stems (structure, mode of construction, role), the collected nutritive particles (source, mode of collection) and the reproduction of this species (with extended parental care?). We consider that the integration of functional traits (behaviour, lifestyle, ecology) is relevant in taxonomy, by aiming to no longer describe only species but also by integrating them in an environmental framework. In a global context (i.e. background deep-sea versus hydrothermal vents), can we consider $D$. dianae as a vent obligate species or a deep-sea species? Accepting that our perception of the vent environments can be biassed by our insufficient knowledge, the exploration of hydrothermal vents must, therefore, be pursued not only by focussing on only these environments but, rather, by considering them in the large context of the Deep Sea. To answer the questions dedicated to $D$. dianae, new sampling and in situ observations with a more accurate methodology will be performed during the next BICOSE cruise (2018).

Acknowledgements The authors would like to thank all the scientific team of the BICOSE cruise (P.I. M. Cambon-Bonavita, Ifremer), especially J. Sarrazin and L. Menot from Ifremer for their help on board. Special thanks to the team of the ROV 'Victor'. Thanks to Jørgen Olesen and Danny Eibye-Jacobsen (ZMUC, University of Copenhagen) for the loan of Dulichiopsis nordlandica specimens from the Thor expedition, to Roberta Salmaso (Museo Civico di Storia Naturale, Verona) for the loan of $D$. nordlandica (Ledoyer's specimens) from the W Mediterranean and to the MNHN iconographic service team (UMSMNHN-CNRS 2700), especially to J.F. Dejouannet for his artistic reconstitution showing two specimens in a resting position on their mast. The authors gratefully acknowledge an anonymous reviewer and M. Thiel (Universidad Católica del Norte, Chile) for their constructive comments, which helped to significantly improve the quality of the manuscript.

\section{References}

Agassiz A (1863) List of the echinoderms sent to different institutions in exchange for other specimens, with annotations. Bull Mus Comp Zool Harvard Univ 1:17-28

Andres HG, Rauschert M (1990) Paradyopedos, eine neue Gattung der Podoceridae aus der Antarktis (Crustacea: Amphipoda: Gammaridea). Mitteilungen aus dem Hamburgischen Zoologischen Museum und Institut 87:171-179

Barnard JL (1964) Some bathyal Pacific Amphipoda collected by the U.S.S. Albatross. Pac Sci 18(3):315-335

Barnard JL, Ingram CL (1990) Lysianassoid Amphipoda (Crustacea) from deep-sea thermal vents. Smithson Contrib Zool 499:1-80 
Bellan-Santini D (2005) Stenothoidae (Crustacea: Amphipoda) of hydrothermal vents and surroundings on the Mid-Atlantic Ridge, Azores Triple Junction Zone. J Nat Hist 39:3435-3452

Bellan-Santini D (2006) Rhachotropis species (Crustacea: Amphipoda: Eusiridae) of hydrothermal vents and surroundings on the MidAtlantic Ridge, Azores Triple Junction zone. J Nat Hist 40:14071424

Bellan-Santini D (2007) New amphipods of hydrothermal vent environments on the Mid-Atlantic Ridge, Azores Triple junction zone. J Nat Hist 41:567-596. https://doi.org/10.1080/00222930701262537

Bellan-Santini D, Thurston MH (1996) Amphipoda of the hydrothermal vents along the mid-Atlantic Ridge. J Nat Hist 30:685-702

Boeck A (1871) Crustacea Amphipoda borealia et arctica. Forh Vidensk Selsk Cristiania 1870:83-280

Carausu A (1941) Note sur quelques caprellides des eaux françaises et monégasques. Bull Inst Océanogr (Monaco) 803:1-15

Copley JTP, Jorgensen PBK, Sohn RA (2007) Assessment of decadalscale ecological change at a deep Mid-Atlantic hydrothermal vent and reproductive time-series in the shrimp Rimicaris exoculata. $\mathrm{J}$ Mar Biol Ass UK 87:859-867

Copley JTP, Tyler PA, Van Dover CL, Schultz A, Dickson P, Singh S, Sulanowska M (1999) Subannual temporal variation in faunal distributions at the TAG hydrothermal mound $\left(26^{\circ} \mathrm{N}\right.$, Mid-Atlantic Ridge). Mar Ecol 20(3-4):291-306

Corbari L, Durand L, Cambon-Bonavita M-A, Gaill F, Compère P (2012) New digestive symbiosis in the hydrothermal vent amphipoda Ventiella sulfuris. C R Biologies 335:142-154

Corbari L, Sorbe JC, Massabuau JC (2005) Video study of the caprellid amphipod Parvipalpus major: morpho-functional and behavioural adaptations to deep-sea bottoms. Mar Biol 146(2):363-371

Cuvelier D, Sarradin P-M, Sarrazin J, Colaço A, Copley JT, Desbruyères D, Glover AG, Santos RS, Tyler PA (2011) Hydrothermal faunal assemblages and habitat characterisation at the Eiffel Tower edifice (Lucky Strike, Mid-Atlantic Ridge). Mar Ecol 32:243-255. https:// doi.org/10.1111/j.1439-0485.2010.00431.x

Dana JD (1849) Synopsis of the genera of Gammaracea. Am J Sci Arts 8: $135-140$

Desbruyères D, Biscoito M, Caprais JC, Colaço A, Comtet T, Crassous P, Fouquet Y, Khripounoff A, Le Bris N, Olu K, Riso R, Sarradin PM, Segonzac M, Vangriesheim A (2001) Variations in deep-sea hydrothermal vent communities on the Mid-Atlantic Ridge near the Azores plateau. Deep Sea Res I 48:1325-1346

Desbruyères D, Laubier L (1980) Alvinella pompejana gen. sp. nov., Ampharetidae aberrant des sources hydrothermales de la ride EstPacifique. Oceanol Acta 3(3):267-274

Desbruyères D, Segonzac M, Bright M (2006) Handbook of deep-sea hydrothermal vent fauna. Denisia 18:1-544

Esposito V, Giacobbe S, Cosentino A, Minerva CS, Romeo T, Canese S, Andaloro F (2015) Distribution and ecology of the tube-dweller Ampelisca ledoyeri (Amphipoda: Ampeliscidae) associated with the hydrothermal field off Panarea Island (Tyrrhenian Sea, Mediterranean). Mar Biodiv 45:763-768

Fricke H, Giere O, Stetter K, Alfredsson GA, Kristjansson JK, Stoffers P, Svavarsson J (1989) Hydrothermal vent communities at the shallow subpolar Mid-Atlantic ridge. Mar Biol 102(425):429

Galkin SV, Sagalevich AM (2017) Endemism and biodiversity of hydrothermal vent fauna. In: Ehrlich $\mathrm{H}$ (ed) Extreme biomimetics. Springer, Cham, pp 97-118

Gebruk AV, Galkin SV, Vereshchaka AL, Moskalev LI, Southward AJ (1997) Ecology and biogeography of the hydrothermal vent fauna of the Mid-Atlantic Ridge. Adv Mar Biol 32:93-144

Gurjanova E (1946) New species of Isopoda and Amphipoda from the Arctic Ocean (in Russian, with English summary). In Trudy drift. Exped. Icebreaker 'G. Sedov' 1937-40. Ed Capt. V. K. Buinitski. Izdatelstvo Glavsevmorputi, Moscow-Leningrad. Vol. 3, pp 272 297
Hirayama A, Takeuchi I (1993) New species and new Japanese records of the Gammaridea (Crustacea: Amphipoda) from Matsukawa-ura Inlet, Fukushima Prefecture, Japan. Publ Seto Mar Biol Lab 36(3): $141-178$

Horton T, Lowry J, De Broyer C (2016) Dulichiidae. In: Horton T, Lowry J, De Broyer C, Bellan-Santini D, Coleman CO, Daneliya M, Dauvin J-C, Fišer C, Gasca R, Grabowski M, Guerra-García JM, Hendrycks E, Holsinger J, Hughes L, Jaume D, Jazdzewski K, Just J, Kamaltynov RM, Kim Y-H, King R, Krapp-Schickel T, LeCroy S, Lörz A-N, Senna AR, Serejo C, Sket B, Tandberg AH, Thomas J, Thurston M, Vader W, Väinölä R, Vonk R, White K, Zeidler W (2017) World Amphipoda Database. Accessed through: World Register of Marine Species at http://www.marinespecies.org/aphia. php? $=$ taxdetails \&id $=236746$ on $2017-08-10$

Jones ML (1981) Riftia pachyptila, new genus, new species, the vestimentiferan worm from the Galápagos Rift geothermal vents (Pogonophora). Proc Biol Soc Wash 93(4):1295-1313

Kaartvedt S, Van Dover CL, Mullineaux LS, Wiebe PH, Bollens SM (1994) Amphipods on a deep-sea hydrothermal treadmill. Deep Sea Res I 41(1):179-195

Krøyer H (1845) Karcinologiske Bidrag. Naturhist Tidsskr Ser 2 1:453638

Larsen K (2007) Amphipoda (Crustacea; Peracarida) from the hydrothermal vent system of the Juan De Fuca Ridge, Escabana trough and Gorda ridge, Northeast Pacific. Part I. Lysianassidae and Sebidae. Zootaxa 1445:1-26

Larsen K, Krapp-Schickel T (2007) Amphipoda (Crustacea: Peracarida) from chemically reduced habitats; the hydrothermal vent system of the north-east Pacific. Part II. Melitidae and Eusiridae. J Mar Biol Assoc UK 87:1207-1217. https://doi.org/10.1017/ S002531540705672X

Latreille PA (1816) Amphipoda. In: Nouveau dictionnaire d'Histoire naturelle, appliquée aux Arts, à l'Agriculture, à l'Économie rurale et domestique, à la Médecine, etc. Par une société de Naturalistes et d'Agriculteurs. Vol. 1. 2nd Edition. Deterville, Paris, pp 467-469

Laubitz DR (1977) A revision of the genera Dulichia Krøyer and Paradulichia Boeck (Amphipoda, Podoceridae). Can J Zool 55(6): 942-982

Laubitz DR (1979) Phylogenetic relationships of the Podoceridae (Amphipoda, Gammaridea). Bull Biol Soc Wash 3:144-152

Laubitz DR (1983) A revision of the family Podoceridae (Amphipoda, Gammaridea). In: Conference on the Biology and Evolution of Crustacea, JK Lowry, ed. Australian Museum Memoir 18:77-86

Leach WE (1814) Crustaceology. The Edinburgh Encyclopaedia 7:383434

Ledoyer M (1986) Faune de Madagascar. Crustacés Amphipodes Gammariens. Familles des Haustoriidae à Vitjazianidae. Éditions de l'ORSTOM 59(2):599-1112

Lowry J, De Broyer C, Costello M, Bellan-Santini D (2010) Dulichiopsis Laubitz, 1977. In: Horton T, Lowry J, De Broyer C, Bellan-Santini D, Coleman CO, Daneliya M, Dauvin J-C, Fišer C, Gasca R, Grabowski M, Guerra-García JM, Hendrycks E, Holsinger J, Hughes L, Jaume D, Jazdzewski K, Just J, Kamaltynov RM, Kim Y-H, King R, Krapp-Schickel T, LeCroy S, Lörz A-N, Senna AR, Serejo C, Sket B, Tandberg AH, Thomas J, Thurston M, Vader W, Väinölä R, Vonk R, White K, Zeidler W (2017). World Amphipoda Database. Accessed through: World Register of Marine Species at http://www.marinespecies.org/aphia.php?p=taxdetails\&id=101735 on 2017-01-05

Lowry JK, Myers AA (2013) A phylogeny and classification of the Senticaudata subord. nov. (Crustacea: Amphipoda). Zootaxa 3610(1): $1-80$

Martin JW, France SC, Van Dover CL (1993) Halice hesmonectes, a new species of pardaliscid amphipod (Crustacea, Peracarida) from hydrothermal vents in the eastern Pacific. Can J Zool 71(9):1724-1732 
Martin JW, Pettit G (1998) Caprella bathytatos new species (Crustacea, Amphipoda, Caprellidae), from the mouthparts of the crab Macroregonia macrochira sakai (Brachyura, Majidae) in the vicinity of deep-sea hydrothermal vents off British Columbia. Bull Mar Sci 63(1):189-198

Mattson S, Cedhagen T (1989) Aspects of the behaviour and ecology of Dyopedos monacanthus (Metzger) and D. porrectus Bate, with comparative notes on Dulichia tuberculata Boeck (Crustacea: Amphipoda: Podoceridae). J Exp Mar Biol Ecol 127:253-272

McCloskey LR (1970) A new species of Dulichia (Amphipoda, Podoceridae) commensal with a sea urchin. Pac Sc 24:90-98

Metzger A (1875) V. Zoologische Ergebnisse der Nordseefahrt. X. Crustaceen aus den Ordnungen. Edriophthalmata und Podophthalmata. Dtsch. Meere Jahresber, pp 277-310

Meyer-Rochow VB, Stephan H, Moro SD (1991) Morphological and anatomical observations on the hairy eyes of males and females of the marine amphipod Dulichia porrecta (Crustacea, Amphipoda, Podoceridae). Ital J Zool 58(1):59-69

Mironov AN, Gebruk AV, Moskalev LI (2002) Biogeography of hydrothermal vent communities and obligate hydrothermal taxa. In: Gebruk AV (ed) Biology of hydrothermal systems. KMK Scientific Press Ltd., Moscow, pp 410-455

Moore PG, Earll R (1985) Sediment "whips": amphipod artefacts from the rocky sublittoral in Britain. J Exp Mar Biol Ecol 90(2):165-170

Myers AA, Cunha MR (2004) New and little known corophiidean amphipods from the 'Lucky Strike' hydrothermal vent, Mid-Atlantic Ridge. J Mar Biol Ass UK 84:1019-1025

Myers AA, Lowry JK (2003) A phylogeny and a new classification of the Corophiidea Leach, 1814 (Amphipoda). J Crust Biol 23:443-485

Rauschert M (1988) Gammaridea (Crustacea, Amphipoda) aus der Ktistenregion von King George (Siid-Shetland-Inseln) Podoceridae. Mitt Zool Mus Berl 64(2):299-310

Rauschert M (1990) Pseudodulichia, eine neue Gattung der Podoceridae aus der Antarktis (Crustacea: Amphipoda: Gammaridea). Zoosyst Evol 66(2):371-374

Rona PA, Klinkhammer G, Nelsen TA, Trefry JH, Elderfield H (1986) Black smokers, massive sulphides and vent biota at the Mid-Atlantic Ridge. Nature 321:33-37

Sars GO (1879) Crustacea et Pycnogonida nova in itinere 2do et 3tio expeditionis Norvegicae anno $1877 \& 78$ collecta. (Prodromus descriptionis). Arch Math Naturvidensk 4:427-476

Sars GO (1895) Amphipoda. An account of the Crustacea of Norway. Alb. Cammermeyers Forlag, 711 pp, 240 pls
Shaw P (1989) New amphipods from geothermal vent sites off the west coast of Vancouver Island, British Columbia, with a reappraisal of the amphipod family Sebidae. Can J Zool 67:1882-1890

Sheader M, Van Dover CL, Shank TM (2000) Structure and function of Halice hesmonectes (Amphipoda: Pardaliscidae) swarms from hydrothermal vents in the eastern Pacific. Mar Biol 136:901-911

Sheader M, Van Dover CL, Thurston MH (2004) Reproductive ecology of Bouvierella curtirama (Amphipoda: Eusiridae) from chemically distinct vents in the Lucky Strike vent field, Mid-Atlantic Ridge. Mar Biol 144:503-514. https://doi.org/10.1007/s00227-003-1211-8

Spence Bate C (1857a) A synopsis of the British edriophthalmous Crustacea. Ann Mag Nat Hist Ser 2 19:135-152

Spence Bate C (1857b) British Amphipoda. Ann Mag Nat Hist Ser 2 19: 271

Stephensen K (1944) Crustacea Malacostraca VIII: Amphipoda IV. Danish Ingolf-Exped 3(13):1-51

Tandberg AH, Rapp HT, Schander C, Vader W, Sweetman AK, Berge J (2012) Exitomelita sigynae gen. et sp. nov.: a new amphipod from the Arctic Loki Castle vent field with potential gill ectosymbionts. Polar Biol 35:705-716. https://doi.org/10.1007/s00300-011-1115-x

Tarasov VG, Gebruk AV, Mironov AN, Moskalev LI (2005) Deep-sea and shallow-water hydrothermal vent communities: two different phenomena? Chem Geol 224:5-39. https://doi.org/10.1016/j. chemgeo.2005.07.021

Thiel M (1997) Reproductive biology of an epibenthic amphipod (Dyopedos monacanthus) with extended parental care. J Mar Biol Ass UK 77:1059-1072

Thiel M (1998) Population biology of Dyopedos monacanthus (Crustacea: Amphipoda) on estuarine soft-bottoms: importance of extended parental care and pelagic movements. Mar Biol 132:209221

Tunnicliffe V (1991) The biology of hydrothermal vents: ecology and evolution. Oceanogr Mar Biol Ann Rev 29:319-407

Vinogradov GM (1993) Amphipods (Crustacea) from hydrothermal vents of the eastern Pacific. Zool Zh 72(2):40-53

Vinogradov GM (1995) Amphipods from hydrothermal vents and cold seepings on the ocean bottom. Oceanology of the Russian Academy of Sciences 35(1):69-74

Williams AB, Rona PA (1986) Two new caridean shrimps (Bresiliidae) from a hydrothermal field on the Mid-Atlantic Ridge. J Crust Biol 6(3):446-462

Wolff T (2005) Composition and endemism of the deep-sea hydrothermal vent fauna. Cah Biol Mar 46(2):97-104 